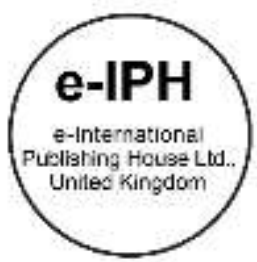

\title{
The Role and Potential of Art for New City Landmark: Case of Kampung Pelangi, Semarang, Indonesia
}

\author{
Effendy Sigit ${ }^{1}$, Nadira Elkalam ${ }^{2}$, Isami Kinoshita ${ }^{1}$ \\ ${ }^{1}$ Environmental Science and Landscape Architecture Course, Graduate School of Horticulture, Chiba University, Japan \\ 2 Urban and Regional Planning, Undergraduate School of Engineering Faculty, Diponegoro University, Indonesia \\ s_mulyansyah@yahoo.com, Nadira.elkalam19@pwk.undip.ac.id, isamikinoshita@faculty.chiba-u.jp \\ Tel: +818098033078
}

\begin{abstract}
Over the last few years, revitalization through painting in the slum area become popular in some cities in Indonesia. The attractive colors and illustrations have escalated the village on social media, especially for youth. The study focuses on investigating the roles of art in Kampung Pelangi potential for city landmark. Interviews and observations were done as a preliminary study, and survey online intended to understand the university students' perception as a youth representative. The results have investigated that despite art has brought the dominant visual in the landscape, the unity with the existing landmark is needed to bring harmony to enhance the current image of the city.
\end{abstract}

Keywords: New urbanism; landmark; the role of art; student's perception

eISSN: 2398-4287 ( 2018. The Authors. Published for AMER ABRA cE-Bs by e-International Publishing House, Ltd., UK. This is an open access article under the CC BYNC-ND license (http://creativecommons.org/licenses/by-nc-nd/4.0/). Peer-review under responsibility of AMER (Association of Malaysian Environment-Behaviour Researchers), ABRA (Association of Behavioural Researchers on Asians) and cE-Bs (Centre for Environment-Behaviour Studies), Faculty of Architecture, Planning \& Surveying, Universiti Teknologi MARA, Malaysia.

https://doi.org/10.21834/e-bpj.v3i9.1541

\subsection{Introduction}

Since many years art and culture have been used as tools to improve the image and make urban spaces attractive. Art was considered as new urbanism which normalizing not only urban space and experience but also art itself. By contributing to decorate an ugly and unsafe public space, the technique could give positive impacts to the physical and aesthetics of the city through the painting the flat wall. The existence of art as part of city development often does not match with the existing character of the town. Thus, donates lack of connectivity to the physical landscape with place meanings within the broader physical, cultural, and emotional context (Ujang, 2012). In recent year social media was contributed to give people access to explore more place through their phone. In this scenario, youth are a key user

\subsection{Issues and Objectives}

Over the last few years, revitalization through painting slum area become popular in some cities in Indonesia. The objective of the movement is to improve the visual quality of the slum settlement. The attractive colors and illustrations have succeeded to bring young people to come and take photos to portray it on social media such as Instagram as it happened in Kampung Pelangi, Semarang. Moreover, the study area located in the central of the town which considered to give a dominant visual for the surrounding landscape through the painting. Therefore, it can threaten the other city's landmarks. Also, users, experience and perception could construct a new image of its place.

Users are the key components of urban places (Ujang, 2012). This study generates youth as an active user who perceived their experience in social media. However, this phenomenon was bringing the question for this study on how young people embrace the new culture and how they recognized the existing landmarks. The paper aim is to investigate the roles of art in Kampung Pelangi potential 
for a new city landmark. Hence, the objectives are to identify the impacts of the movement and the influence of art through painting in the context of a university student's perceptions. University student as youth representative who embraces the new culture. According to the study by Zebracki (2013) educational background leaves a significant impact on how the public perceives public art.

\subsection{Literature Review}

\subsection{Art as new urbanism}

The concept of new urbanism was fostering the quality of life and placemaking. It integrates perceptual, functional and behavioral dimensions with sustainable environmental ideas (Elshater, 2012). Urbanism is related to the concept of revitalization, renewal, and transformation of a place or community. It drives to the aspects of aesthetics, appropriateness, and quality of architecture (Elshater, 2012). This paper focuses on its criteria with a dimension of visual quality, legibility and identity, beautiful image, meaning and urban aesthetics. Art has been seen as a new alternative and effective to stimulate and activate in an urban area and harmonies in urban space (Sakip, Bahaluddin, \& Hassan, 2016). Besides that development of art in urban planning contributes to normalization public open space (Guinard \& Margier, 2017).

Moreover, art in the city believed as an excellent contribution for city image or place. An identifiable and robust image would have a positive impact on the citizen. The good image of the place can improve the quality of life (QOL). It is seen as an alternative to activate the lost space in the urban area towards the quality of life in the city (Sakip et al., 2016). Therefore, the existence of art in the city needs to consider. Important art in public spaces become more connected with the concept of revitalization (Ursic, 2014). Roles of art, in particular, place, have been seen as a tool to re-enchant the urban imaginary.

On the other hand, simultaneously to remove the negative impacts and create a positive urban image (Guinard \& Margier, 2017). Art as new urbanism believed that takes a role to improve aesthetics quality of the city (Elshater, 2012), giving specific importance to the image and city identity. Image of the city strengthens where the public arts create new nodes and spaces and vice versa (Omar, Sakip, \& Akhir, 2016).

Identity covers many concepts like architectural, social, cultural. City identity can be appeared through the visual object and creates an image of the city (lynch, 1960). Visual element takes an important role to give people's perception. Visual quality also raised the recognizability and imageability of the city.

The first painted village in Indonesia was started since 1980 in Kali Code, Yogyakarta known as Kampung Warna-Warni (picturesque village). After that, the similar concept was applied to some cities in Indonesia. In general, the objective of the movement is to transform the image of slum settlement become more attractive through painting. Art by painting believed can give colorful in the village and reflecting the local culture. Also increasing the economy and local tourism.

\subsection{Student's perceptions of public art}

Young people in the city influences to determine the image of its city. Suthasupa (2012) Indicate that young people are better in abstract thinking how do they investigate the image with the regards the city they live in and the environment around them. The latest trend, trendsetters, and advertisement can influence youth easily. They tend to be more attracted to new things and trend (Ismail \& Nadarajah, 2016). That tendency to considered how young people embrace the new culture. From his study, Zebracki (2013) describe that discussed educational background leaves a significant impact on how public art perceived by the public. Higher education people can interpret the meaning that artworks try to convey, whether positively or negatively. Ismail \& Nadarajah (2016) elaborate that young people are tend to find something interesting in a particular place as a reason for them to appreciate.

\subsection{Methodology 3.2 Study Area}

This study was conducted in Kampung Pelangi, Semarang city, Indonesia. It is capital city for central Java province located in northern of Java island and directly bordered with Java sea (see fig 1). The strategic location made Semarang city become the most visited place during the colonial time especially from sea lanes to conduct military, trading, government, and other activities. According to Rachmawati (2004) stated that big cities in Indonesia considered as a center of city development, which Semarang city has Simpang Lima as a city center categorizes as a node (Lynch, 1960). During the colonial period, city center (nodes) used by the citizen as a place for taking rest and doing some trading. Now, some of the nodes have changed function as city landmarks. People used it as a guide and an indication that they were in Semarang city.

Kampung Pelangi (Rainbow village) become popular in online media after the success of revitalization slum area by painting the flat wall. The project initiated and funded by the local government to renovate the village to give a magnificent vision of the Pasar Bunga Kalisari (flower market). At first, the idea comes from an old teacher who inspired by other asian areas which have a similar transformation (Coffey, 2017). The original name of Kampung Pelangi was Kampung Brintik that located near two famous landmarks in Semarang city which is Tugu Muda and Lawang Sewu. The hilly topography makes Kampung Pelangi can be seen from the area that has a lower elevation. This unique location made Kampung Pelangi brings a dominant visual in the surrounding landscape. The transformation was escalated Kampung Pelangi as a must-see attraction and trending in social media (Cofey,2017). Therefore, it easy to attract people to come especially young people to take photos and uploaded on the internet. It is evidence that Kampung Pelangi was popular in media social such as Instagram. According to Christopher Pycroft, Development Manager Douglas Development Partnership, Isle of Man, 2009, mentioned that physical and visual landmarks public art can also become cultural landmarks where people can meet, and mini-cultures can develop. Media online has contributed to promotes some particular places through sharing the experience in public space in the digital culture (Zebracki, 2017). There are 22.500 photos have been uploaded by using hashtag \#kampungpelangi, 
and 7456 posted \#kampungpelangisemarang (See Fig. 2). Its phenomenon potential to bring new city landmark and threaten the other monument and to lose city identity if there is no decent planning especially in the digital era. Fig. 2: Hashtag using on Instagram by use keywords "\#kampungpelangi and \#ampungpelangisemarang"

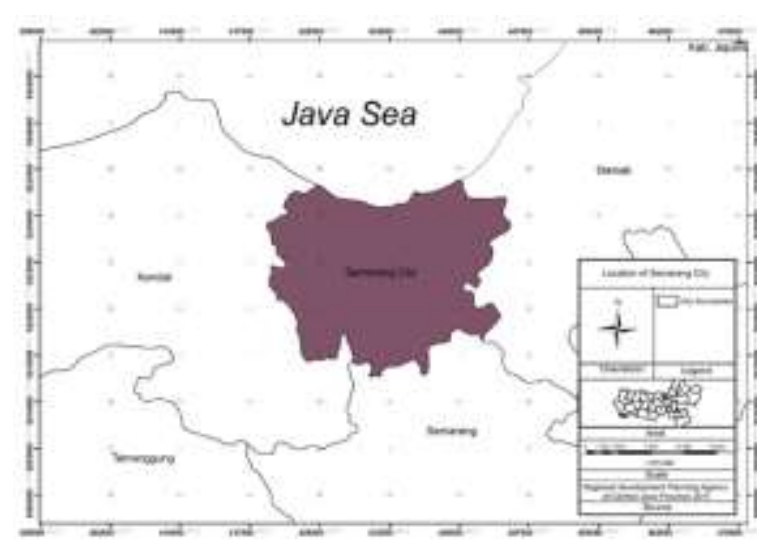

(a)

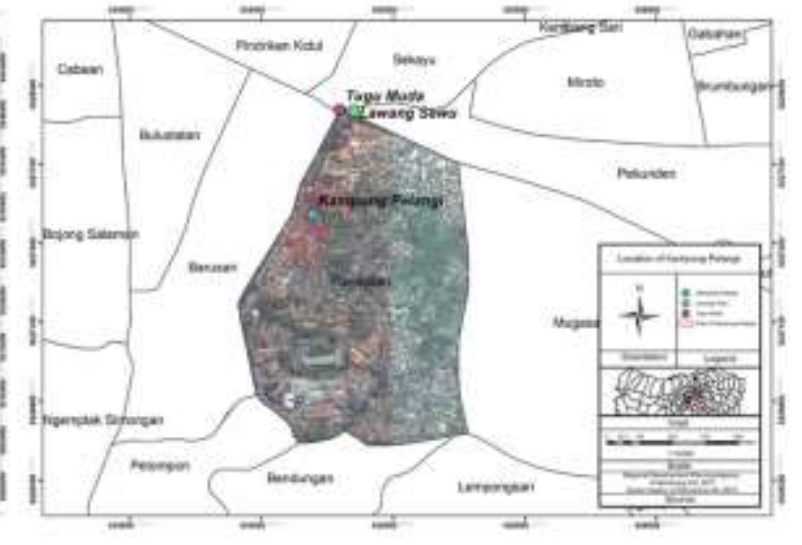

(b)

Fig. 1. (a) Location of Semarang city; (b) Location of Kampung Pelangi. (Source: Author)

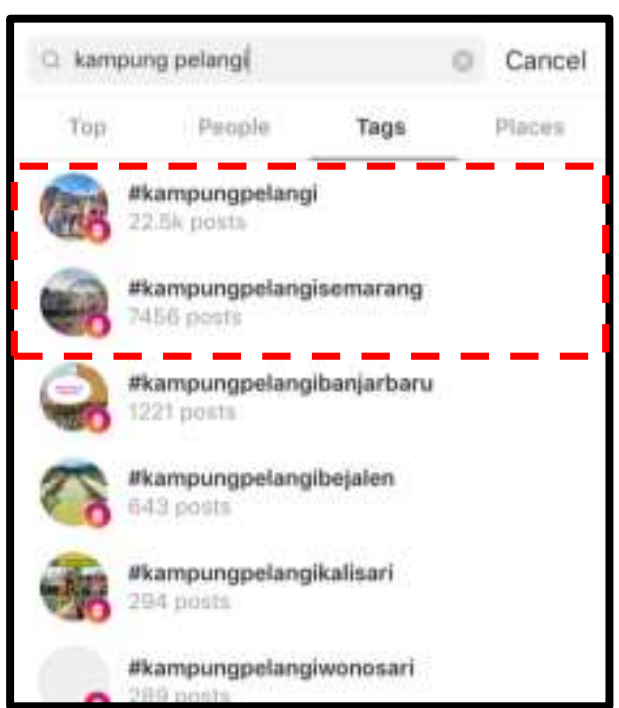

Fig. 2. The use hashtag "kampung pelangi" and "kampung pelangi semarang" on social media (Source:"Instagram" (access 25 August 2018))

\subsection{Collecting data}

\subsubsection{Preliminary study}

The preliminary study was conducted by identifying the related keywords (i.e., Kampung Pelangi, public art, identity). The collected keywords are used to gather data from the internet, books, and related journal regarding the phenomenon occurs. To get deeply understanding, semi-structured interviews were carried out to the community leader and leader of the project ("Pokdarwis"). The interviews intended to find out the motive behind the movement and if there is a community involvement. The observations were carried out by collecting photos to investigate the physical improvement after the movement through painting.

\subsubsection{Questionnaire research}

The questionnaire was carried out by the online survey used to collect the data regarding the perception of roles of art in Kampung Pelangi potential for new city landmark. The survey online was distributed to university students in Semarang city as a representative of youth. Purposive sampling technique was used to conduct the survey. In this technique, each respondent has an equal chance of being 
selected as the subject. The survey was completed in 14 days and collected a total of 76 respondents. The questionnaire output processed on the Excel table.

\subsubsection{Limit of the study}

The limit of the study is only addressed one type of sample respondents. Therefore, the findings may be insufficient to explain the roles of art as potential for city landmark. The small samples might affect the result.

\subsection{Results and discussions}

\subsection{Art project in Kampung Pelangi}

At first, the community leader was mentioned that the painting project influenced by the revitalization of the flower market which located near the village. Therefore, the local government was initiated to renovate the visual of the Kampung Pelangi because the slum impression was giving ugly views for its surrounding. The strategic location of Kampung Pelangi believed to bring new point for the city, to increase the tourism and local economy.

"Pokdarwis" known as a creative organizer stated that the beginning of the project was started with the paint with the giving maximum three colors for each house. The involvement of the local community to painting is low, most of them are just following the process of painting. Although some houses decorated from ideas of the house owner, on the other hand, it brings a lack of harmony in the overall theme of the painting. The aesthetics evaluations are shown in the table below.

The results from both interviews were identified that there is no decent planning regarding painting project. Lack of community involvement and the it feels just for temporary project.

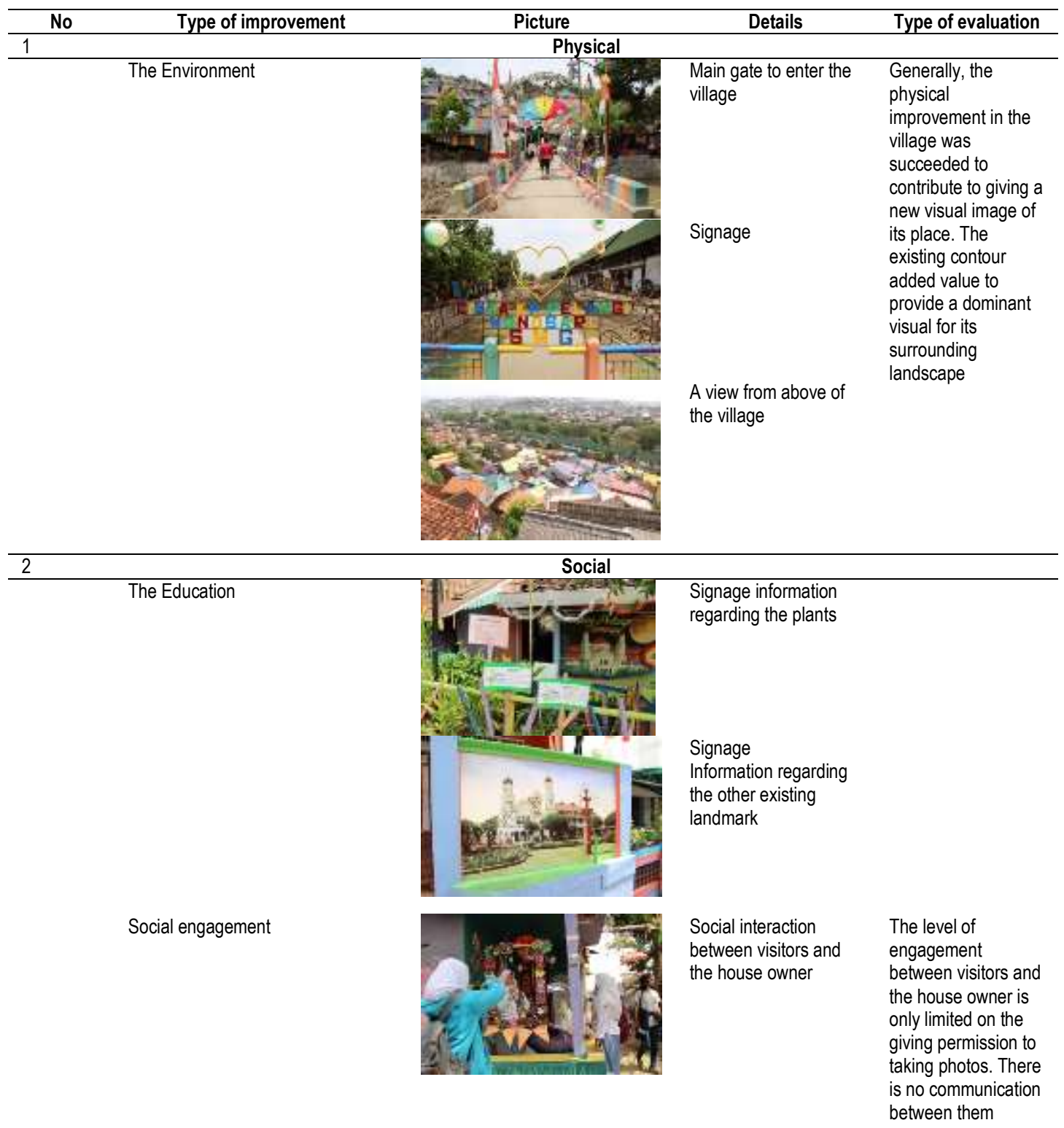




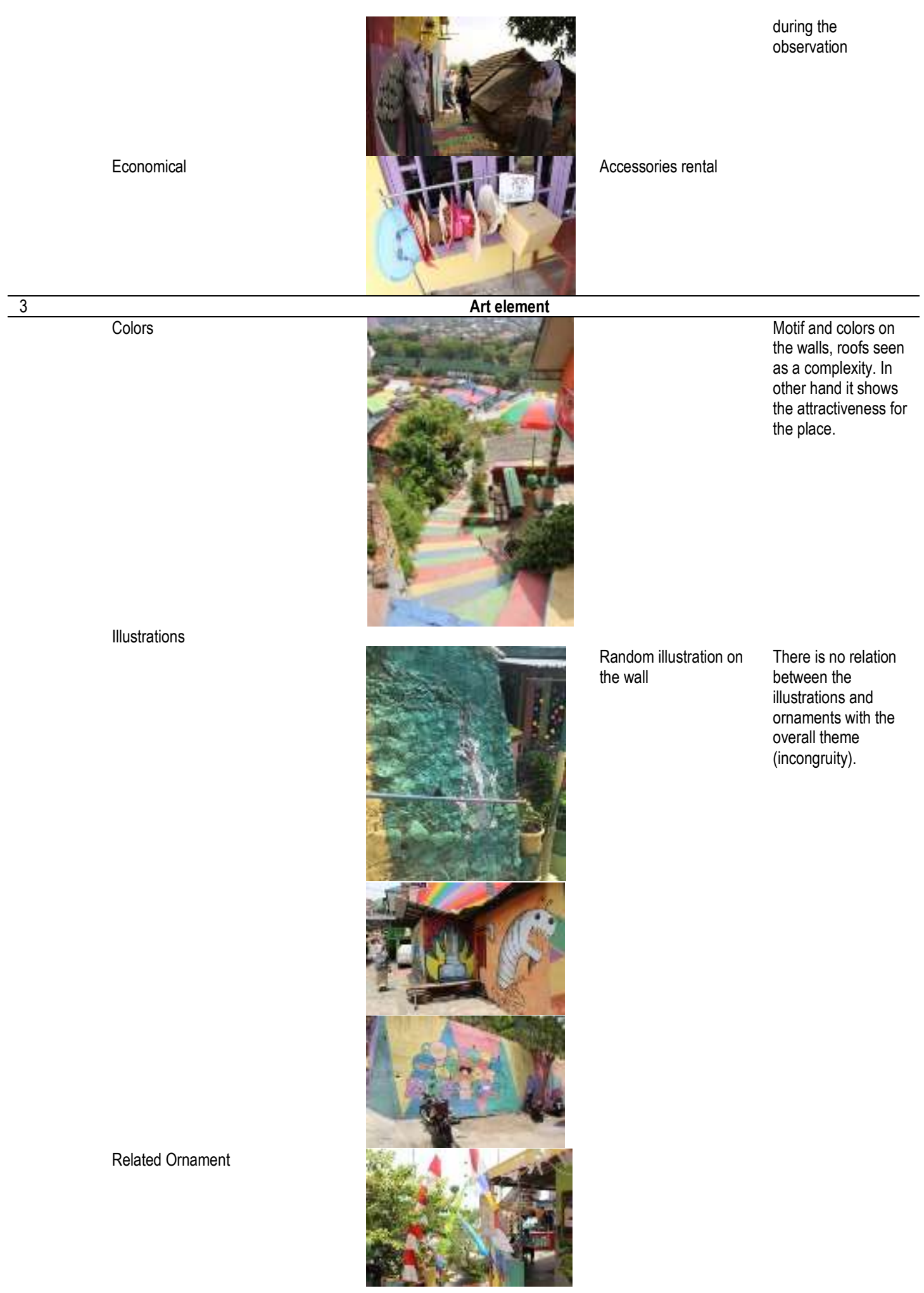




\section{The questionnaires res}

\subsection{The Attributes of respondent}

The result from online surveys $(n=78)$ obtained data that $78.9 \%$ were female and $21.1 \%$ were male with age range of $19-20$ years old $(38.2 \%)$. Most of the respondents are originally come from outside of Semarang city and its surroundings. The majority length of stay is $2-3$ years $(42.1 \%)$. In addition, the majority background of the study is urban planning, this allows certain trends in the survey results

\subsection{Perception Semarang city and its identity}

The result shows most of the student perceived image of Semarang city as a historical city $(72.4 \%)$. They argued the remaining historic building and its landscape had an influenced to perceive the city image. The most commonly recognize landmark was Lawang Sewu $(53.9 \%)$ as a heritage building, while Simpang Lima (21.8\%) was recognize as public open space. Moreover, students conveyed that the historical heritage scattered around the city is not only used as a city landmark but also it provides a tourist attraction. Therefore, the location of Kampung Pelangi surrounded by various monuments potential to threaten the other city landmarks (See Fig. 3). This situation considered as the negative impact to overall character and image of the city. Therefore, it essential to review the existing role and element of the city as part of city development. The decent planning by using art as part of city development can enhance the value of the existing image. Moreover, the social media (32.1\%) had helped them to get information about the landmarks (32.1\%). It is as a consideration online media can have a significant influence in providing location and geographical information more effectively, especially for young people to access the information.

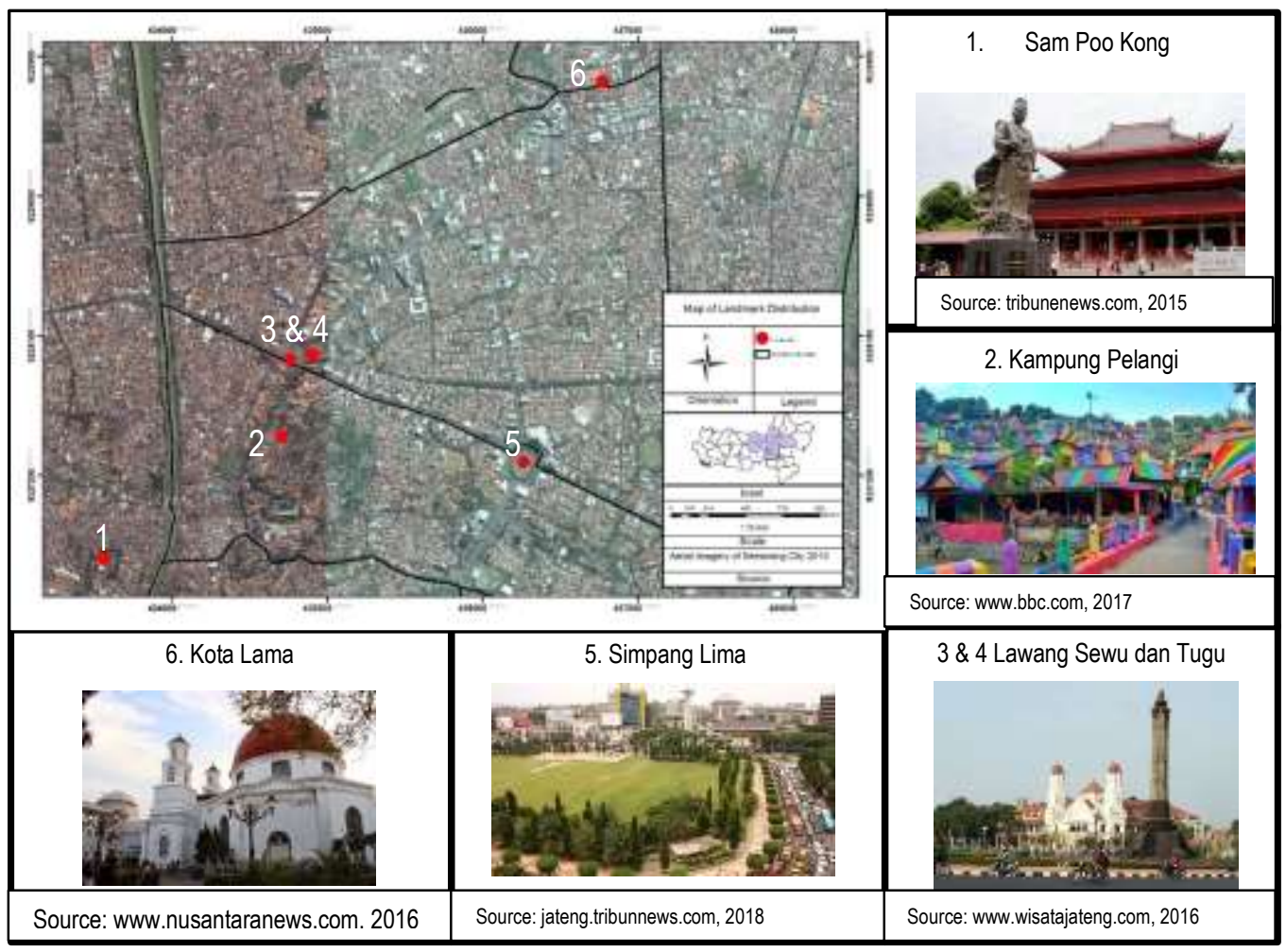

Fig. 3: Map of landmark distribution

(Source: Author)

\subsection{Roles of art potential for new city landmark}

Kampung Pelangi as one of the cases for revitalized slum settlement in the urban area by using art. The village becomes popular after published in many online articles local and international to discuss the existence of Kampung Pelangi. It shows the majority of respondents (98.7\%) knew the presence of Kampung Pelangi and most of them had visited it (53.8\%). Although, the reason they attended because of study and research (48.9\%), while the presence of the attractive colors still on interest $(31.9 \%)$. The art elements such as colors and illustrations on the wall have given positive impacts to change the image of Kampung Pelangi it shows that most respondents are agreed with it (63.6\%). Students believed that the contribution of art in Kampung Pelangi was able to give an innovation for revitalization slum area. Also, it provides the opportunity to enhance the dominant visual in surrounding landscape, brings new characteristics, and given a new identity of the place from the slum, dull and unsafe to become cleaner, visually integrated and interesting for tourist. Moreover, it potentially to increase economic value in local tourism.

Although art judged by subjectivity, roles of art in spatial study potential to provide positive and negative impacts. By painting the dull walls in Kampung Pelangi, art contributes to improving visual quality through increased recognizability and imageability of the area. The dominant visual has potential affecting the surrounding landscape including its city landmarks $(35.1 \%)$. Most of the respondents believed 
these factors brought a potential for new city landmark (43.6\%). Besides that, respondents pointed out that the other factors such as location. Moreover, accessible of Kampung Pelangi was promoted it to seen as a contrast to the overall image of the city.

Meanwhile, the other respondents (42.3\%) did not agree that Kampung Pelangi potential for new city landmark. They assumed this movement has only recently existed. Therefore, most of the visitors are more familiar with the other city landmarks which have lived for a long time. Plus, the image of Semarang city itself is rated as a historical city by some respondents.

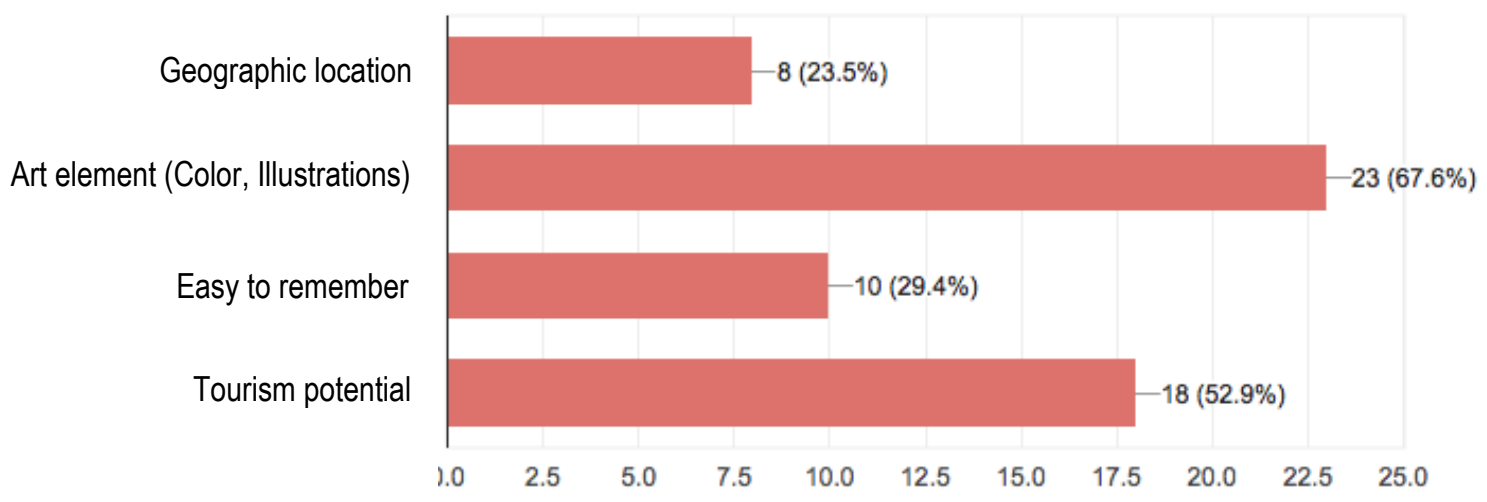

Fig. 4. Graphic of potential factors for new city landmark in Kampung Pelangi

The phenomenon of painting slums into rainbow color has been applied in several cities in Indonesia, thus eliminating the original character of the area. Rainbow themes that have used in many cities also make Kampung Pelangi in Semarang less attractive for tourist's second visits. Visitors assume that Kampung Pelangi in Semarang will be the same as other decorative villages in other cities.

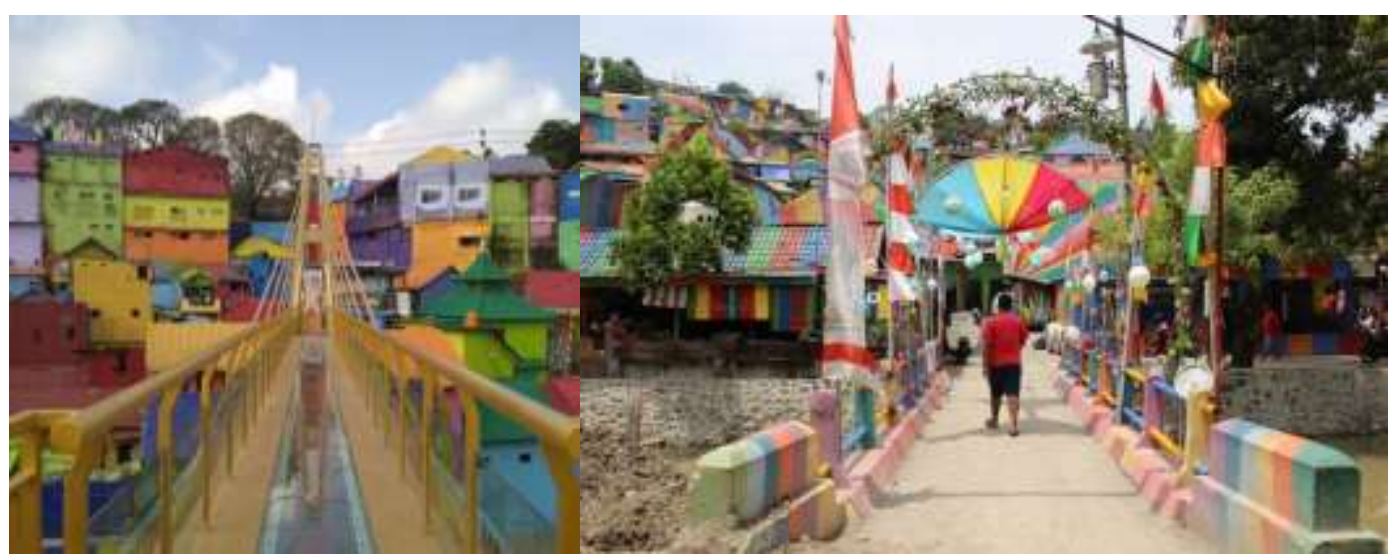

(a)

(b)

Fig. 5. The Similar rainbow concept (a) Jodipan Village, Malang city; (b) Kampung pelangi, Semarang city.

(Source: Author)

\subsection{Conclusion}

The study has shown that the contribution of art in slum settlement potential to presents the excitement of the young people although still lack of community involvement towards the process of painting. The decent planning by using art as part of city development is needed. Its potential to enhance the value of the existing image. Although, the phenomenon of painting slums area into rainbow color had been applied in several places, thus eliminating the original character of the area. This phenomenon has been seen just as a temporary improvement. An Image of the city needs to be considered to give a sustainable in a landscape. It is a need for integrated planning by unifying the existing urban elements and a new concept of new urbanisms as a whole concept. Moreover, the contribution of the young people in this study offered a different perspective on new urbanism. Further investigation is needed to consider more perceptions of the residence on the village regarding participation planning.

\section{Acknowledgment}

This study is a part of doctoral research at Chiba University and supported by the Ministry of Education, Culture, Science and Technology (MEXT) scholarship. 


\section{References}

Coffey, H. (2017, May 17). Kampung has become Indonesia's latest must visit attraction after unveiling an eye-water new look. Retrieved from independent.co.uk

Elshater, A. (2012). New Urbanism Principles versus Urban Design Dimensions towards Behavior Performance Efficiency in Egyptian Neighbourhood Unit. Procedia Social and Behavioral Sciences, 68, 826-843. https://doi.org/10.1016/j.sbspro.2012.12.270

Guinard, P., \& Margier, A. (2017). Art as a new urban norm: Between normalization of the City through art and normalization of art through the City in Montreal and Johannesburg. Cities, 77(June 2017), 13-20. https://doi.org/10.1016/j.cities.2017.04.018

Ismail, W. H. W., \& Nadarajah, J. R. s/o. (2016). Young Visitors in the City: Their Perceptions of Heritage Buildings. Procedia - Social and Behavioral Sciences, 234, 470477. https://doi.org/10.1016/j.sbspro.2016.10.265

Omar, S. S., Sakip, S. R. M., \& Akhir, N. M. (2016). Bringing the New to the Old: Urban Regeneration through Public Arts. Procedia - Social and Behavioral Sciences, 234, 515-524. https://doi.org/10.1016/j.sbspro.2016.10.270

Sakip, S. R. M., Bahaluddin, A., \& Hassan, K. (2016). The Effect of Mural on Personal Crime and Fear of Crime. Procedia - Social and Behavioral Sciences, 234(2012), 407-415. https://doi.org/10.1016/j.sbspro.2016.10.258

Suthasupa, S. (2012). The Portrayal of a City's Image by Young People. Procedia - Social and Behavioral Sciences, 38(December 2010), $284-292$. https://doi.org/10.1016/j.sbspro.2012.03.350

Ujang, N. (2012). Place Attachment, Familiarity and Sustainability of Urban Place Identity. Procedia - Social and Behavioral Sciences, 49(February), 156-167. https://doi.org/10.1016/j.sbspro.2012.07.014

Ursic, M. (2014). ' City as a work of art ' - Influence of public art in the city.

Zebracki, M. (2013). Beyond public artopia: Public art as perceived by its publics. GeoJournal, 78(2), 303-317. https://doi.org/10.1007/s10708-011-9440-8

Zebracki, M. (2017). A cybergeography of public art encounter: The case of Rubber Duck. International Journal of Cultural Studies, $20(5)$, 526-544. https://doi.org/10.1177/1367877916647142 